\title{
ACTA ICHTHYOLOGICA ET PISCATORIA
}

Vol. XXV, Fasc. 1

Szczecin 1995

Włodzimierz ZAEACHOWSKI, Irena KRZYKAWSKA

Fish biology

\author{
GROWTH RATE OF ROACH - Rutilus rutilus (L.) \\ IN LAKE DABIE \\ TEMPO WZROSTU PEOCI - Rutilus rutilus (L.) \\ W JEZIORZE DĄBIE
}

\section{Department of Fish Biology, Agricultural University of Szczecin, Poland}

\begin{abstract}
Length and weight growth rates of roach as well as the lenght-weight relationship were determined from 196 individuals caught in 1992. Separate determinations were made for males and females and for different age groups. The von Bertalanffy equation and the binomial model were used to determine growth. Significance of differences between results obtained for 6 samples of different size, collected within July - October, was compared. Differences between growth rate indicators for the period 1974 -1976 and 1992 were evaluated.
\end{abstract}

\section{INTRODUCTION}

A research program on "Growth rate of fish in the unstable environment of the River Odra estuary system" (supported by the State Committee for Scientific Research from funds diverted to statutory activities) was launched in 1992 . The work, reported here, on growth rate of roach in the Lake Dąbie is thus a part of a comprehensive project. 
In terms of its surface area $\left(56 \mathrm{~km}^{2}\right)$, Lake Dąbie is the fourth largest freshwater reservoir in Poland. Due to its location within the City of Szczecin, it is exposed to the runoff of municipal and harbour effluents. Additionally, agricultural effluents reach the lake from the east. The hydrochemical regime is unstable and dependent upon the river discharge and the range of the Baltic water inflows [Tadajewski and Rutkowski 1993; Bastidas 1994].

The estuarine nature of the lake and its advanced eutrophication affect living conditions of the fish. The effect can be to some extent reflected in the growth rate: The very rich set of data on roach growth in several hundred Polish lakes, published by Wilkońska [1975], can serve as a reference. It has also been possible to compare temporal changes, as the growth rate of the Lake Dąbie roach was determined in the seventies within the framework of a research project, supported by the Institute of Meteorology and Water Management, on effects of the Dolna Odra power plant cooling water. The data [Filipiak et al. 1975, 1976], so far unpublished, are fully comparable with those used in this work as the fish age was determined by the same persons. The seventies' data served to additionally calculate the von Bertalanffy model parameters in this work.

Apart from evaluating the Lake Dąbie roach growth rate in relation to data collected from other Polish lakes and in relation to temporal changes in the lake itself, the present paper touches upon still another matter. To assess the representativeness of samples of different size, results yielded by several samples collected during one year were compared and significance of differences relative to the overall mean was determined.

\section{MATERIALS AND METHODS}

A total of 196 roach individuals, caught in traps within July - October 1992, were examined. The fish were measured to 0.1 or $0.5 \mathrm{~cm}$ and weighted whole to $1 \mathrm{~g}$. Both the total (1.t) and body (1.c. = longitudo corporis) lengths were recorded. The latter value was used in all the tables and can be converted to the former with the equation.

$$
\text { 1.t. }=0.57+1.1733 \text { 1.c. }(\mathrm{r}=0.9987)
$$

All the fish except 4 individuals, which were disregarded in growth rate determinations, were sexed. The fish age was determined from scales collected from above the lateral line on the left-hand side of the body. Growth rings on scales of individuals aged up to 10 years were distinct. Growth rate was determined using the Rosa Lee formula applied to back-calculations. Fig. 1 shows the linear relationship between the caudal radius (R) and the body length (1.c.). The correction factor (1.c. at $R=0$ ) was $0.8 \mathrm{~cm}$, i.e. underestimated relative to the mean value of $1.55 \mathrm{~cm}$ calculated by Heese [1992] from measurements made also on small fish.

Table 1 provides a detailed description of the 6 samples, while Figs 2-3 show length and age distributions, respectively, of all the individuals examined. Females, twice as abundant as males, prove more long lived and, consequently, larger.

Significance of differences in fish growth between groups of individuals assembled according to various criteria (date of capture, sex, etc.) was tested with the Student's t test. Lengths obtained from back-calculations were used when calculating the von Bertalanffy models. The length-weight relationship was determined with the power function, whereas a modified von Bertalanffy equation served to determine the weight growth rate. 


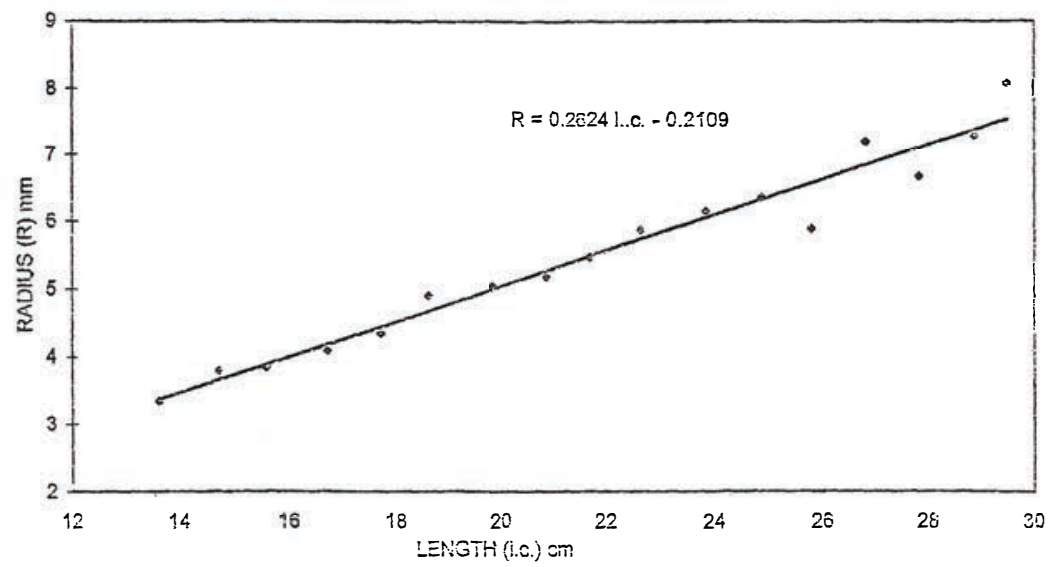

Fig.1. Scale radius $(\mathbb{R})$ - body length (1.c.) relationship

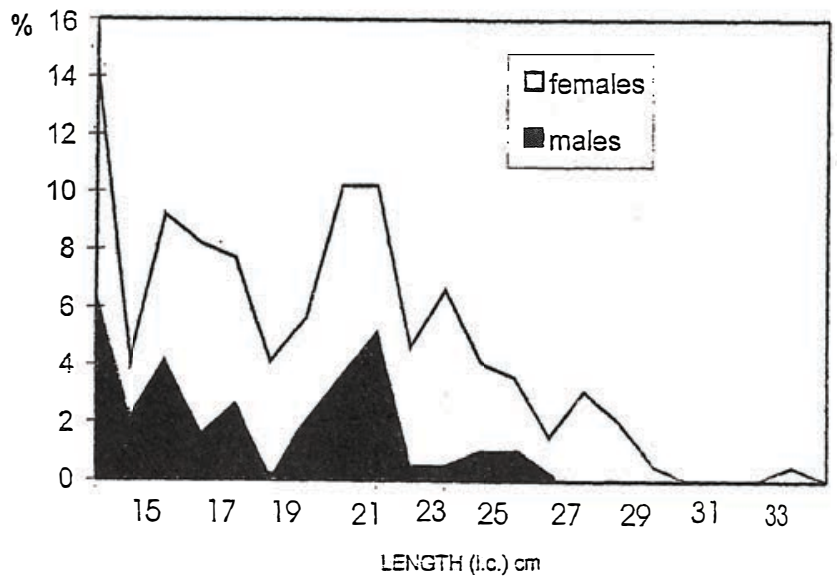

Fig. 2. Sex-dependent length distribution of the roach examined

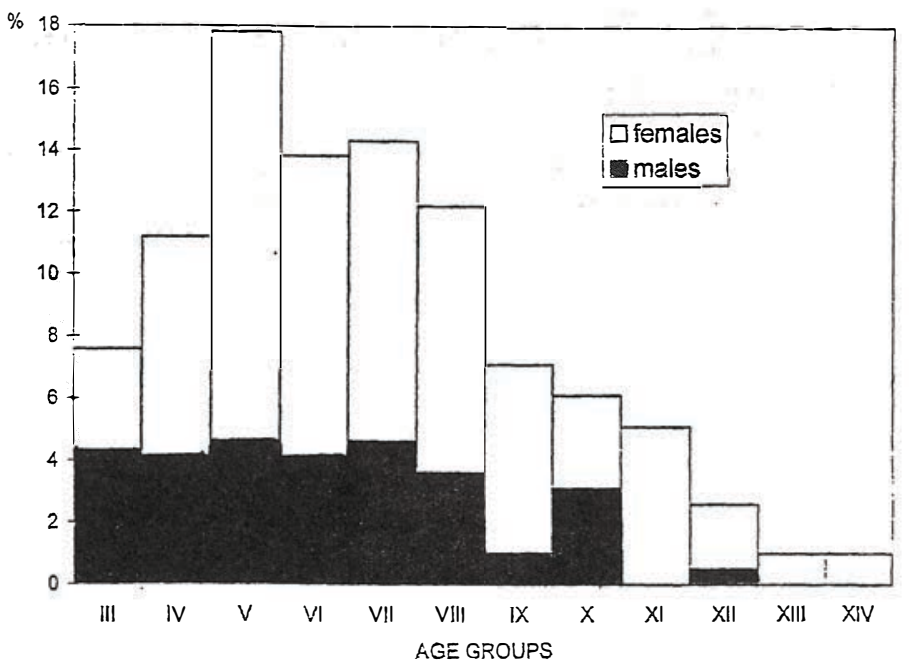

Fig. 3. Age distribution of individuals of both sexes 
The binomial and the growth coefficient (GL) as determined by Szypuła [1977] were applied to analysis of length growth rate in different age groups. The growth coefficient is an integer determined within the interval of 0 to $t_{\max }$ of the binomial growth equation. The coefficient was slightly modified here as year 10 instead of $t_{\max }$ was included as the upper limit of the integer.

Table 1

Description of samples collected in 1992

\begin{tabular}{|l|c|c|c|c|c|c|c|c|}
\hline \multicolumn{1}{|c|}{$\begin{array}{c}\text { Date of } \\
\text { fishing }\end{array}$} & \multicolumn{2}{|c|}{ Males } & \multicolumn{2}{c|}{ Females } & \multicolumn{2}{c|}{ Sex indetermined } & \multicolumn{2}{c|}{ Total } \\
\cline { 2 - 10 } & $\mathrm{n}$ & $\begin{array}{c}\text { length range } \\
\text { l.c. cm }\end{array}$ & $\mathrm{n}$ & $\begin{array}{c}\text { length range } \\
\text { l.c. cm }\end{array}$ & $\mathrm{n}$ & $\begin{array}{c}\text { length range } \\
\text { l.c. cm }\end{array}$ & $\mathrm{n}$ & $\begin{array}{c}\text { length range } \\
\text { l.c. cm }\end{array}$ \\
\hline 10 Jully & 14 & $13.5-23.5$ & 12 & $13.5-29.5$ & 2 & $14.0-21.5$ & 28 & $13.5-29.5$ \\
\hline 17 July & 7 & $21.0-22.0$ & 19 & $18.5-28.5$ & 2 & $21.0-21.5$ & 28 & $18.5-28.5$ \\
\hline 28 August & 8 & $15.0-22.5$ & 26 & $13.0-29.0$ & & & 34 & $13.0-29.0$ \\
\hline 28 September & 15 & $13.0-22.0$ & 33 & $13.5-33.5$ & & & 48 & $13.0-33.5$ \\
\hline 12 October & & & 16 & $15.2-28.0$ & & & 16 & $15.2-28.0$ \\
\hline 21 October & 14 & $13.5-24.5$ & 28 & $13.0-29.0$ & & & 42 & $13.0-29.0$ \\
\hline Total & 58 & $13.0-24.5$ & 134 & $13.0-33.5$ & 4 & $14.0-21.5$ & 196 & $13.0-33.5$ \\
\hline
\end{tabular}

\section{RESULTS}

Table 2 shows the back-calculation data separately for each of the 6 samples examined as well as means for all the individuals collected in 1992. Differences between lengths in individual samples and the overall mean were regarded as a measure of growth rate variation. The differences proved statistically significant for 2 samples, within a limited period of the roach life in both: the fish caught on 10 July grew to a significantly larger size between years 2 and 6 , while those caught on 28 September grew to a significantly smaller size between years 2 and 5 . Sample means between those extremes and in the fish older than 6 years did not produce significant differences, when compared to the overall mean (except for 2 instances, year 1 and 7 , in the 28 August sample). Noteworthy was the fact that the growth rate in year 1 was uniform: only the difference between the smallest mean length (28 August) and the overall mean bordered on the significance, the difference amounting to as little as $0.21 \mathrm{~cm}$.

As the between-sample differences could have been produced by taking males and females together into account, Table 3 contains data arranged separately for males and females, but only for those samples which showed extreme values in Table 2. Among the females, the 10 July sample is still significantly different from the overall female mean, but for 4 years of life (years 3 to 6) only, while only one length in the 28 September sample showed a difference bordering on the significance. Similar was the case among males: 3 significant differences (years 3 to 5) were retained in the 28 September sample, a single significant difference (year 3 ) being found in the 10 July sample: 
Table 2

Variability in length (1.c. cm) growth rate in the samples

( $n$ - number of individuals; $S$, standard deviation; $t^{0}$, empirical value of test function.

Boldface in dicates significant differences at $p=0.05$ )

\begin{tabular}{|c|c|c|c|c|c|c|c|c|c|c|c|c|c|c|c|}
\hline \multirow{2}{*}{$\begin{array}{l}\text { Date of } \\
\text { sampling }\end{array}$} & \multicolumn{15}{|c|}{ Age } \\
\hline & & 1 & 2 & 3 & 4 & 5 & 6 & 7 & 8 & 9 & 10 & 11 & 12 & 13 & 14 \\
\hline \multirow{4}{*}{10 July } & 1.c. & 5.05 & 8.42 & 11.60 & 14.08 & 16.42 & 18.68 & 20.09 & 22.22 & 21.40 & 23.23 & 24.65 & 26.80 & 27.80 & 28.90 \\
\hline & $\mathrm{n}$ & 26 & 26 & 26 & 18 & 16 & 14 & 10 & 6 & 3 & 3 & 2 & 1 & 1 & 1 \\
\hline & $\pm S$ & 0.78 & 1.52 & 1.59 & 1.29 & 1.87 & 2.23 & 2.57 & 3.37 & 1.04 & 0.71 & 1.34 & & & \\
\hline & $t^{\circ}$ & 0.77 & 2.86 & 3.97 & 3.54 & 3.24 & 2.70 & 1.51 & 1.96 & 0.41 & 0.02 & 0.13 & & & \\
\hline \multirow{4}{*}{17 July } & 1.c. & 4.93 & 7.78 & 10.19 & 12.53 & 14.78 & 16.96 & 18.99 & 20.54 & 22.00 & 22.97 & 26.10 & 26.90 & & \\
\hline & $\mathrm{n}$ & 26 & 26 & 26 & 26 & 26 & 26 & 23 & 16 & 9 & 3 & 1 & 1 & & \\
\hline & $\pm S$ & 0.62 & 1.14 & 1.27 & 1.18 & 1.25 & 1.35 & 1.21 & 1.41 & 1.29 & 1.43 & & & & \\
\hline & $t^{0}$ & 0.16 & 0.33 & 0.38 & 0.42 & 0 & 0.02 & 0.18 & 0.10 & 0.27 & 0.33 & & $-t^{2}$ & & \\
\hline \multirow{4}{*}{28 August } & 1.c. & 4.74 & 7.43 & 10.11 & 12.60 & 14.36 & 16.15 & 17.34 & 19.42 & 21.20 & 22.50 & 24.27 & 24.35 & 28.00 & \\
\hline & $\mathrm{n}$ & 34 & 34 & 34 & 33 & 27 & 21 & 12 & 9 & 9 & 7 & 6 & 2 & 1 & \\
\hline & $\pm S$ & 0.40 & 0.96 & 1.31 & 1.35 & 1.47 & 1.78 & 1.70 & 2.21 & 2.47 & 3.01 & 3.13 & 3.46 & & \\
\hline & $t^{\circ}$ & 1.99 & 1.28 & 0.71 & 0.23 & 1.08 & 1.59 & 2.23 & 1.53 & 0.89 & 0.79 & 0.51 & 1.06 & & \\
\hline \multirow{4}{*}{$\begin{array}{c}28 \\
\text { September }\end{array}$} & 1.c. & 4.93 & 7.26 & 9.61 & 12.00 & 13.89 & 16.26 & 18.71 & 19.91 & 21.51 & $\mid 23.09$ & 24.22 & 25.25 & 26.00 & 25.80 \\
\hline & $\mathrm{n}$ & 48 & 48 & 48 & 47 & 38 & 25 & 20 & 13 & 9 & 7 & 5 & 2 & 2 & 1 \\
\hline & $\pm S$ & 0.60 & 1.08 & 1.73 & 2.02 & 2.45 & 3.23 & 3.45 & 1.25 & 1.48 & 1.43 & 1.70 & 0.64 & 1.13 & \\
\hline & $\mathfrak{t}^{\circ}$ & 0.21 & 2.39 & 2.73 & 2.78 & 2.41 & 1.32 & 0.30 & 1.05 & 0.50 & 0.21 & 0.60 & 0.58 & 0.73 & \\
\hline \multirow{4}{*}{12 October } & 1.c. & 4.79 & 7.51 & 10.17 & 12.56 & 14.69 & 16.56 & 18.97 & 21.07 & 22.72 & 24.00 & 25.43 & 27.00 & & \\
\hline & n & 16 & 16 & 16 & 16 & 15 & 9 & 8 & 7 & 5 & 3 & 3 & 2 & & \\
\hline & $\pm S$ & 0.55 & 0.79 & 1.12 & 1.29 & 1.01 & 1.34 & 1.52 & 1.49 & 1.44 & 1.31 & 1.59 & 1.41 & & \\
\hline & $t^{\circ}$ & 1.04 & 0.65 & 0.35 & 0.26 & 0.18 & 0.54 & 0.08 & 0.78 & 1.07 & 0.61 & 0.41 & 0.55 & & \\
\hline \multirow{4}{*}{21 October } & 1.c. & 5.14 & 7.98 & 10.62 & 13.01 & 15.40 & 17.53 & 19.26 & 20.61 & 22.24 & 23.94 & 27.05 & 28.30 & & \\
\hline & $\mathrm{n}$ & 42 & 42 & 42 & 38 & 34 & 26 & 22 & 17 & 9 & 8 & 2 & 1 & & \\
\hline & $\pm S$ & 0.54 & 0.97 & 1.25 & 1.45 & 1,75 & 1.93 & 2.15 & 1,73 & 2.01 & 2.26 & 0.49 & & & \\
\hline & $t^{\circ}$ & 1.91 & 1.46 & 1.21 & 1.18 & 1.72 & 1.18 & 0.66 & 0.24 & 0.61 & 0.81 & 1.35 & & & \\
\hline & 1.c. & 4.95 & 7.70 & 10.31 & 12.61 & 14.78 & 16.97 & 18.90 & 20.49 & 21.83 & 23.26 & 24.87 & 26.13 & 26.95 & 27.35 \\
\hline 21 October & $\mathrm{n}$ & 192 & 192 & 192. & 178 & 156 & 121 & 95 & & 44 & 31 & 19 & 9. & 4 & 2 \\
\hline . & $\pm S$ & 0.59 & 1.15 & 1.54 & 1.63 & 1.92 & 2.23 & 2.32 & 1.88 & 1.76 & 2.01 & 2.16 & 1.92 & 1.28 & 2.19 \\
\hline
\end{tabular}


The data in Table 3 evidence sex-dependent differences in growth rate. The fact that the differences between mean lengths were significant in the initial two and the final three years of life compared, those in the mid-life (years 3 - 7) being non-significant, can be explained by a change occurring as the fish grew: males grew faster as juveniles, while females grew faster in later years. As a result; the growth curves cross over, as illustrated in Fig. 4 in which the growth rate is based on the von Bertalanffy equation. The curve representing all the individuals is much closer to that of the females, which is a consequence of prevalence of females among the fish examined.

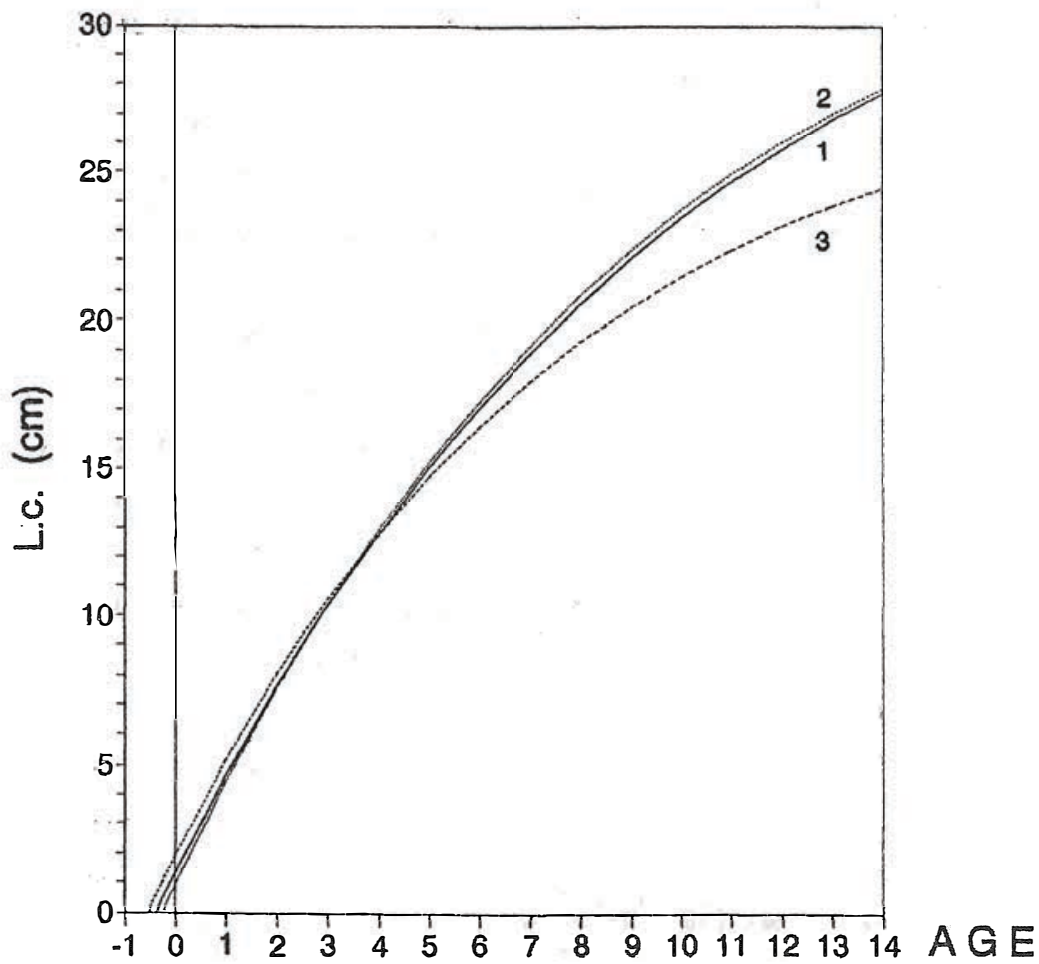

Fig. 4. Length growth curves plotted from the von Bertalanffy model;

1 , entire 1992 sample; 2 , females; 3, males (equation parametres as in Table 7).

Table 4 groups the fish caught in 1992 by age. Each age group represents a generation born in a different calendar year, between 1978-1989. The data give no evidence that in certain years growth of the roach from at least several age groups would be faster or slower than in other years. The table gives also the binomial terms which describe the growth rate of each generation. In this case the binomial seems to be more appropriate than the von Bertalanffy equation as the beginning of growth is located at point 0 of the time axis. This renders the growth coefficient, i.e. the area between the growth curve and the time axis, comparable. The coefficient used was that determined by the integer covering the year 0 - year 10 interval. The highest coefficient (161) was recorded for the roach aged 3 , the values decreasing from 150 to 134 as the fish grew older. 
Variability in length (1.c. cm) growth rate of males and females (for explanation see Table 2)

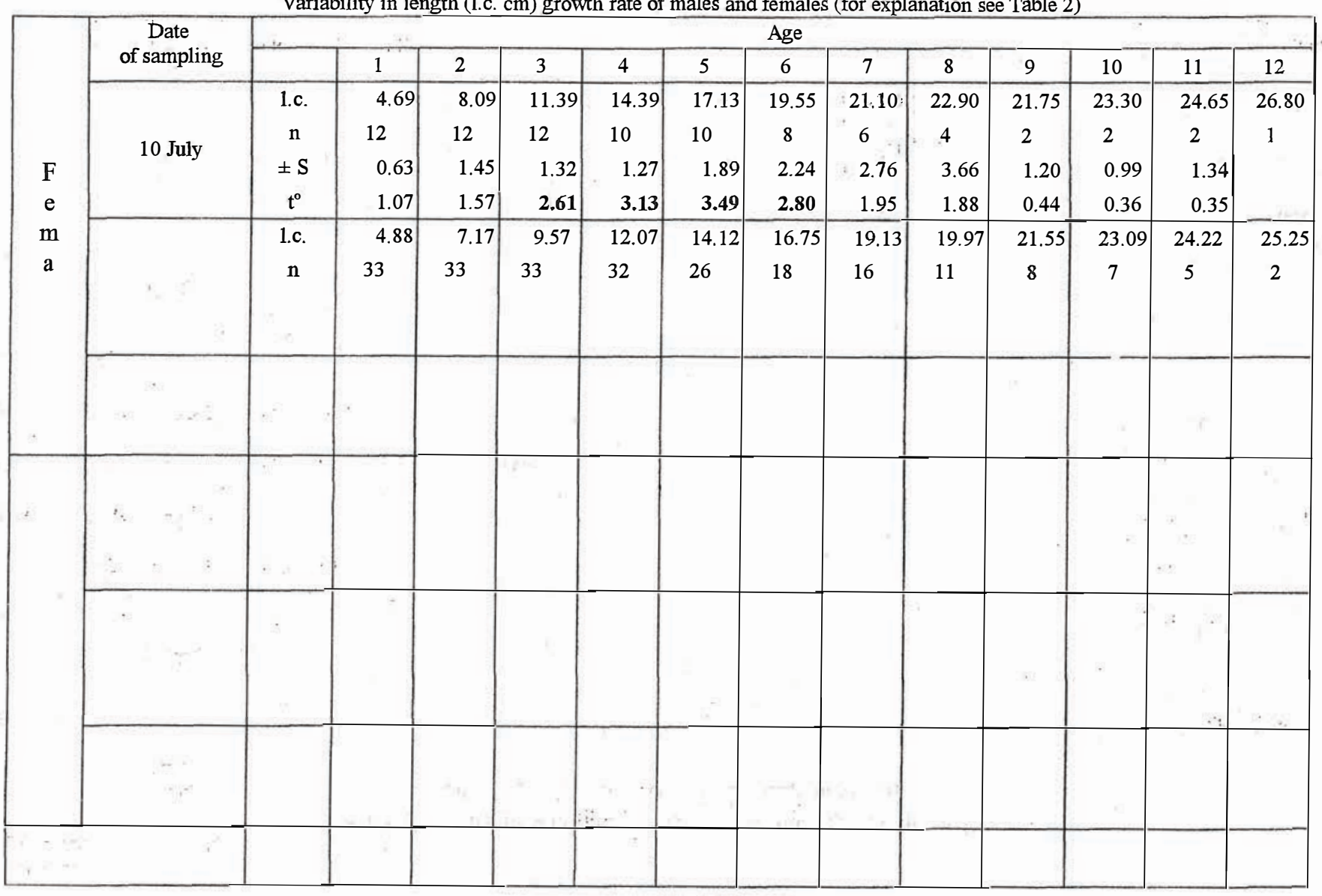


Table 4

Length (1.c. cm) growth rate of roach in various age groups in 1992

$\left[\mathrm{GL}=\int_{0}{ }^{10}\left(\mathrm{a}+\mathrm{bt}+\mathrm{ct}^{2}\right) d \mathrm{t}, \mathrm{t}=\right.$ time in years $]$

\begin{tabular}{|c|c|c|c|c|c|c|c|c|c|c|c|c|c|c|c|c|c|c|c|}
\hline \multirow[t]{2}{*}{ Age group } & \multirow[t]{2}{*}{$\mathrm{n}$} & \multicolumn{14}{|c|}{ Age } & \multicolumn{4}{|c|}{ 1.c. $=a+b t+c t^{2}$} \\
\hline & & 1 & 2 & 3 & 4 & 5 & 6 & 7 & 8 & 9 & 10 & 11 & 12 & 13 & 14 & $\mathrm{a}$ & $\mathrm{b}$ & c & GL \\
\hline III & 14 & 5.6 & 9.2 & 12.1 & & & : & & i & & & 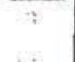 & & & & 2.01 & 3.830 & -0.150 & 161 \\
\hline IV & 22 & 5.1 & 8.0 & 10.9 & 13.4 & & & & & & & & & & & 1.90 & 3.280 & -0.100 & 150 \\
\hline V & 35 & 4.7 & 7.1 & 9.7 & 12.6 & 14.8 & & & & & & & & & & 2.02 & 2.613 & -0.007 & 148 \\
\hline VI & 26 & 4.6 & 7.6 & 19.6 & 13.3 & 15.4 & 18.0 & & & & & & & & $\because$ & 1.41 & 3.306 & -0.092 & 149 \\
\hline VII & 27 & $5: 1$ & 8.0 & 10.7 & 13.1 & 15.4 & 17.7 & 19.9 & & & & & & & & 2.17 & 3.030 & -0.072 & 149 \\
\hline VIII & 24 & 4.9 & 7.7 & 10.3 & 12.6 & 14.7 & 17.0 & 19.1 & 21.3 & & & & & & & 2.32 & 2.749 & -0.049 & 144 \\
\hline IX & 13 & 5.0 & 7.5 & 10.1 & 12.3 & 14.5 & 16.5 & 17.2 & 20.6 & 22.3 & & . & & & & 2.74 & 2.490 & -0.038 & 139 \\
\hline $\mathrm{X}$ & 12 & 4.8 & 7.7 & 10.1 & 12.3 & 14.2 & 16.1 & 17.8 & 19.5 & 21.2 & 22.8 & & & & & 2.44 & 2.688 & -0.067 & 137 \\
\hline XI & 10 & 4.6 & 7.0 & 9.6 & 12.0 & 13.8 & 15.6 & 17.6 & 19.8 & 21.8 & 23.6 & 24.8 & & & & 2.13 & 2.559 & -0.044 & 135 \\
\hline XII & 5 & 4.9 & 7.2 & 9.1 & 11.3 & 13.7 & 15.8 & 18.0 & 20.1 & 21.8 & 23.6 & 25.1 & 26.2 & & & 2.15 & 2.546 & -0.042 & 135 \\
\hline XIII & 2 & 4.5 & 7.1 & 8.9 & 11.7 & 13.2 & 15.5 & 18.2 & 20.6 & 22.2 & 23.5 & 24.9 & 26.2 & 27.4 & & 1.44 & 2.792 & -0.060 & 134 \\
\hline XIV & 2 & 4.5 & 6.8 & 9.6 & 11.9 & 13.9 & 16.6 & 18.9 & 20.6 & 21.7 & 23.0 & 24.4 & 25.8 & 26.5 & 27.3 & 1.18 & 3.067 & -0.086 & 137 \\
\hline
\end{tabular}



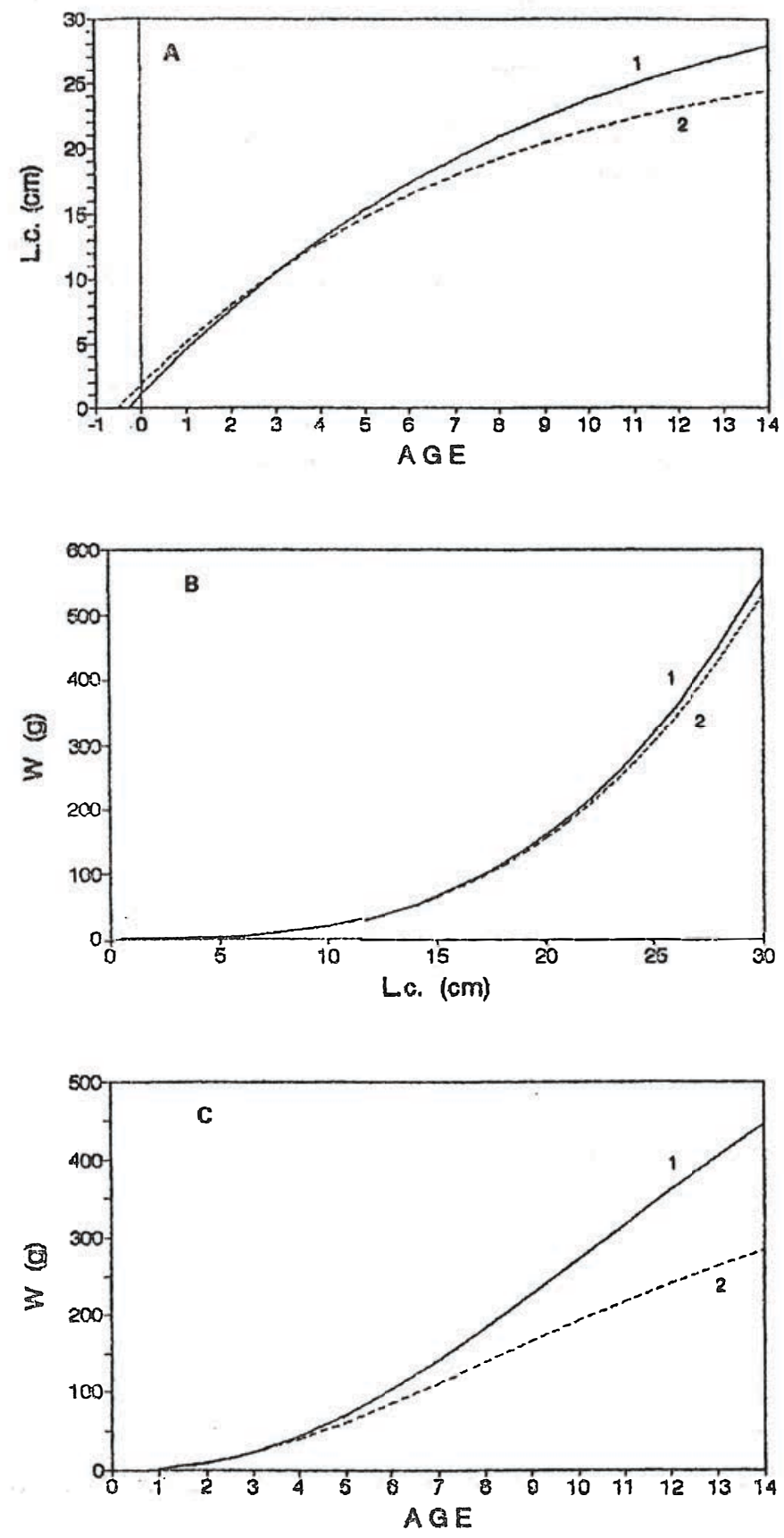

Fig. 5. Growth rate of roach females (1) and males (2); A, length growth; B, length-weight relationship; C, weight growth (equation parameters as in Table 7 ). 
The weight growth rate was calculated once the length-weight relationship was determined. The relationship proved similar for both sexes (Fig. "5). As, however, body weight is proportional to the length cube, the difference between weight girowth rate of females and males is more pronounced than that in the length growth. This is illustrated in Fig.5 in which the von Bertalanffy equation was used to plot the growth curves of both sexes. The point of inflection of the weight growth curves, indicating the age at which annual increments start to diminish, falls at year 11 in females and at year 9 in males.

Table 5 compares the 1992 data with those obtained in the seventies. It was only in 4 out of 40 cases examined that the differences between mean length for the two periods were significant. However, even the significant differences produced a range as small as $0.5-1.2 \mathrm{~cm}$ in the 15-23 cm length classes. Three out of the four significant differences mentioned were found in the materials obtained in 1975; indeed, the growth curve plotted from those data deviates most from a compact bunch of curves presented in Fig.6. The bunch starts to split as late as past year 10, the differences in the younger fish being almost imperceptible.

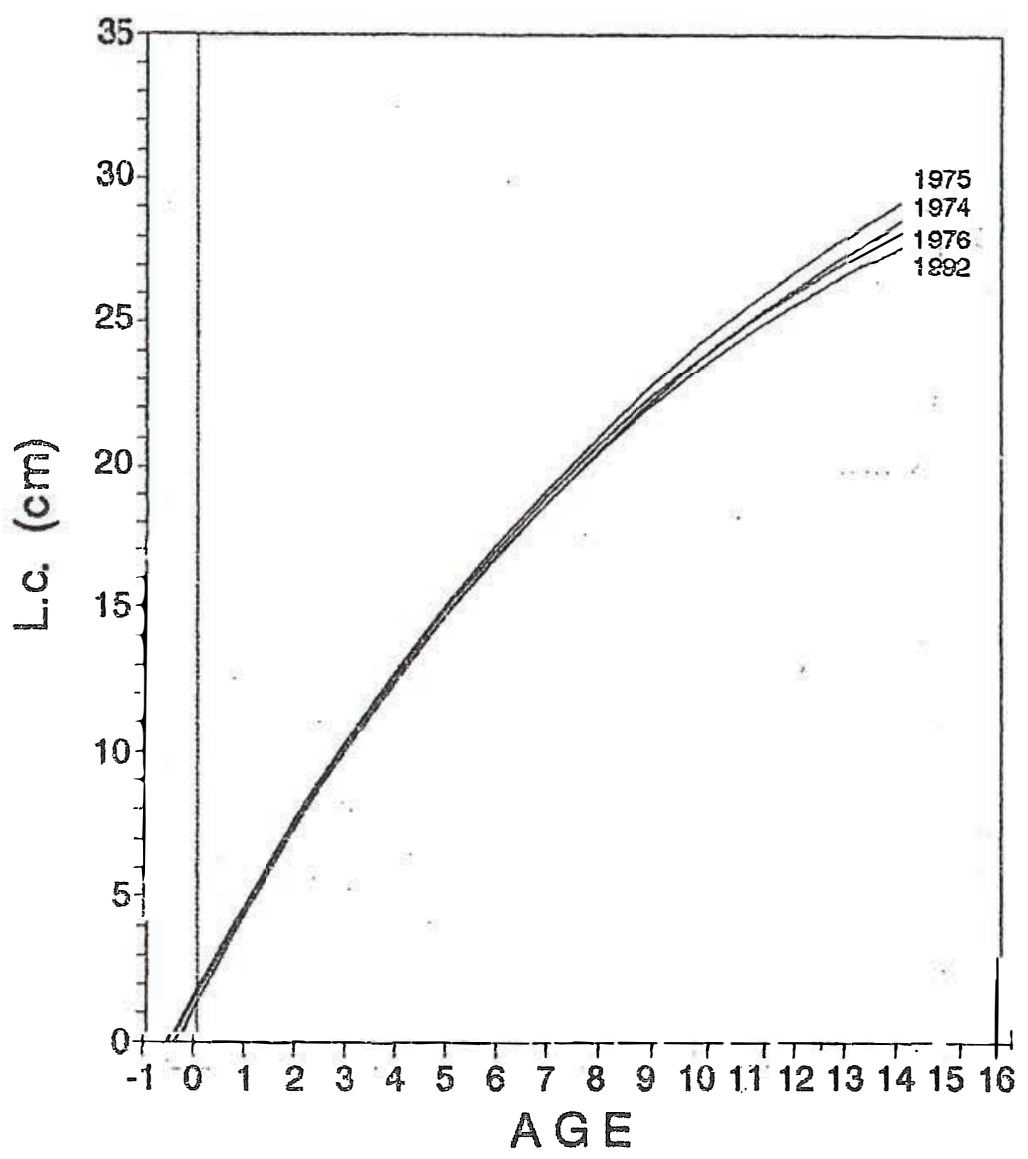

Fig. 6. Length growth rate in different calendar years (von Bertalanffy equation parameters as in Table 7) 
Length (l.c. cm) growth rate of roach caught in various years

Table 5 (for explanation see Table 2)

\begin{tabular}{|c|c|c|c|c|c|c|c|c|c|c|c|c|c|c|c|c|}
\hline \multirow{2}{*}{ Year } & \multicolumn{16}{|c|}{ Age } \\
\hline & & 1 & 2 & 3 & 4 & 5 & 6 & 7 & 8 & 9 & 10 & 11 & 12 & 13 & 14 & 15 \\
\hline \multirow{3}{*}{1992} & 1.c. & 5.0 & 7.7 & 10.3 & 12.7 & 14.8 & 17.0 & 18.9 & 20.5 & 21.8 & 23.3 & 24.9 & 26.1 & 27.0 & 27.4 & \\
\hline & $\mathbf{n}$ & 192 & 192 & 192 & 178 & 156 & 121 & 95 & 68 & 44 & 31 & 19 & 9 & 4 & 2 & \\
\hline & $\pm \mathbf{S}$ & 0.59 & 1.15 & 1.54 & 1.63 & 1.92 & 2.23 & 2.32 & 1.88 & 1.76 & 2.01 & 2.16 & 1.92 & 1.28 & 2.19 & \\
\hline \multirow{4}{*}{1974} & 1.c. & 4.9 & 7.6 & 10.4 & 12.6 & 14.8 & 16.8 & 18.8 & 20.5 & 22.6 & 24.0 & 25.1 & 26.2 & 27.4 & 29.7 & 31.5 \\
\hline & $\mathbf{n}$ & 200 & 200 & 199 & 150 & 105 & 73 & 42 & 29 & 24 & 20 & 18 & 10 & 8 & 4 & 1 \\
\hline & $\pm \mathbf{S}$ & 0.60 & 0.93 & 1.28 & 1.52 & 1.75 & 1.97 & 2.06 & 2.20 & 1.91 & 2.04 & 1.83 & 1.51 & 1.56 & 0.48 & \\
\hline & $t^{0}$ & 1.66 & 0.95 & 0.70 & 0.57 & 0.00 & 0.63 & 0.24 & 0.00 & 1.71 & 1.18 & 0.29 & 0.12 & 0.40 & 1.64 & \\
\hline \multirow{4}{*}{1975} & 1.c. & 4.9 & 7.7 & 10.4 & 13.0 & 15.3 & 17.5 & 19.7 & 21.2 & 23.0 & 24.4 & 25.1 & 27.0 & 26.6 & 28.5 & 29.8 \\
\hline & $\mathrm{n}$ & 221 & 221 & 220 & 182 & 129 & 94 & 55 & 35 & 28 & 18 & 10 & 4 & 1 & 1 & 1 \\
\hline & $\pm \mathbf{S}$ & 0.63 & 0.37 & 1.34 & 1.77 & 1.78 & 2.10 & 1.58 & 2.35 & 2.64 & 2.84 & 2.91 & 3.51 & & & \\
\hline & $t^{0}$ & 1.65 & 0.00 & 0.70 & 1.67 & 2.25 & 1.66 & 2.26 & 0.00 & 2.28 & 1.55 & 0.20 & 0.55 & & & \\
\hline \multirow{4}{*}{1976} & 1.c. & 4.9 & 7.5 & 10.2 & 12.7 & 14.9 & 17.3 & 19.3 & 21.1 & 22.6 & 23.9 & 25.1 & 25.9 & 27.5 & 27.9 & 27.9 \\
\hline & $\mathbf{n}$ & 213 & 213 & 213 & 212 & 189 & 166 & 116 & 86 & 51 & 36 & 24 & 14 & 4 & 2 & 1 \\
\hline & $\pm \mathbf{S}$ & 0.44 & 0.92 & 1.06 & 1.23 & 1.39 & 1.57 & 1.59 & 1.83 & 1.63 & 1.61 & 1.70 & 1.83 & 0.88 & 1.06 & \\
\hline & $t^{0}$ & 1.94 & 1.94 & 0.77 & 0.00 & 0.56 & 1.33 & 1.47 & 1.98 & 2.27 & 1.33 & 0.33 & 0.24 & 0.56 & 0.29 & \\
\hline
\end{tabular}



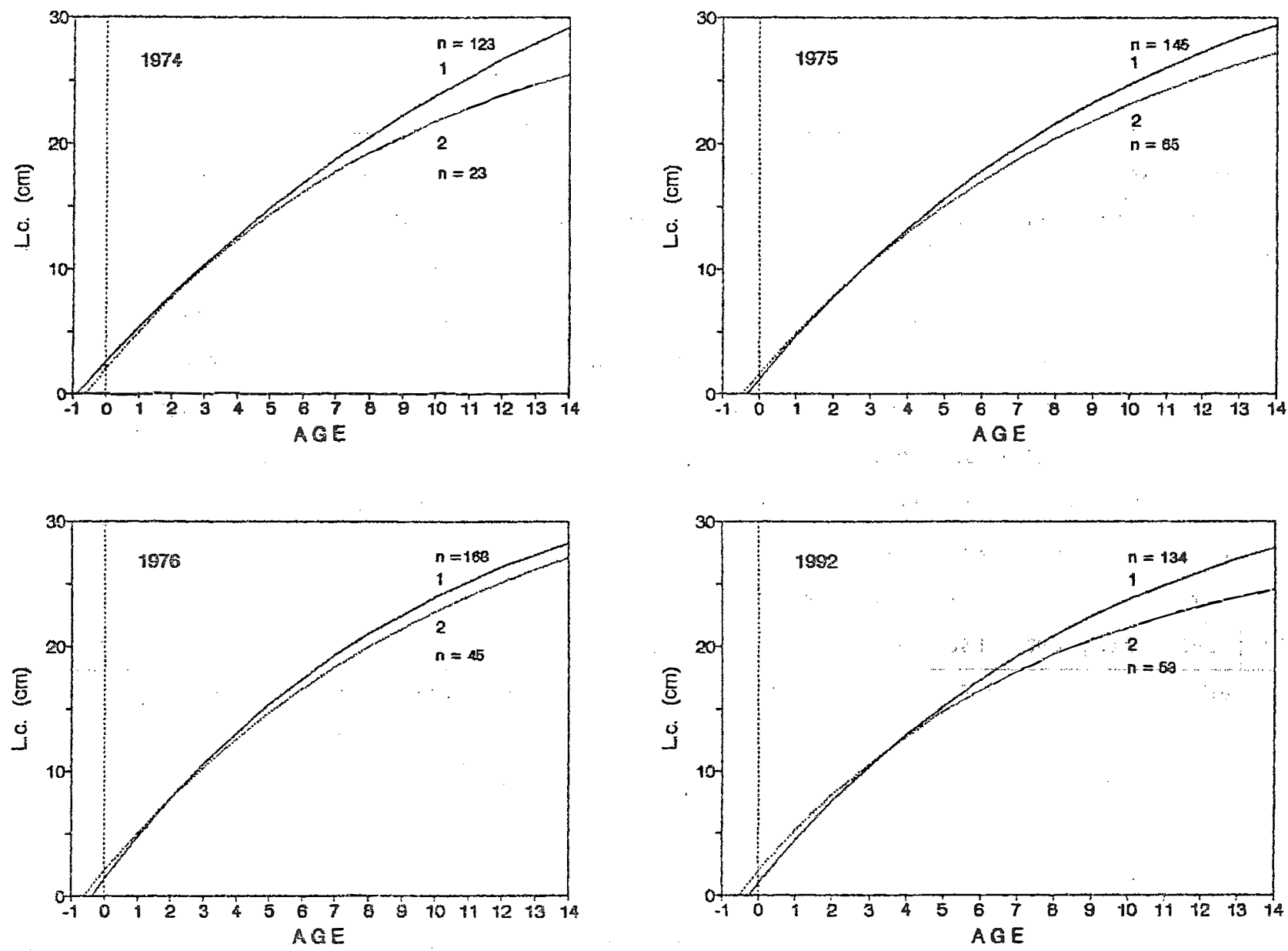

Fig. 7. Growth rate of females (1) and males (2) in different calendar years ( $\mathrm{n}=$ sample size) (von Bertalanffy equation parameters in Table 7 ) 
Two additional criteria confirm the similarity between growth rates of the roach caught in 1992 and in the seventies. The first is the difference between growth rates of males and females. As shown in Fig.7, the difference was the same in all the samples compared. In all the samples, females grew larger than males with time, while in three samples (except for the 1974 one) a slightly faster growth of males was initially observed.

The other criterion involves the growth rates of fish belonging to different age groups. In Table 6, values of growth length coefficient, calculated from the binomial (as in Tab.4) are compiled. A similar decreasing trend of the coefficient with fish age is seen in all the data sets compared; additionally, if age group 3 is disregarded, the coefficient values are similar, regardless of the year of sampling.

Table 6

Variability in length growth rate of roach in various age groups, as measured with growth coefficient $\mathrm{GL}={ }_{0}{ }^{10}\left(\mathrm{a}+\mathrm{bt}+\mathrm{ct}^{2}\right) d t \quad(\mathrm{t}$-time in years)

\begin{tabular}{|c|c|c|c|c|c|c|c|c|}
\hline \multirow{3}{*}{$\begin{array}{l}\text { Age } \\
\text { group }\end{array}$} & \multicolumn{8}{|c|}{ Years } \\
\hline & \multicolumn{2}{|c|}{1974} & \multicolumn{2}{|c|}{1975} & \multicolumn{2}{|l|}{1976} & \multicolumn{2}{|l|}{1992} \\
\hline & $\mathrm{n}$ & GL & $\mathrm{n}$ & GL & \begin{tabular}{l|l}
$\mathrm{n}$ \\
\end{tabular} & GL & \begin{tabular}{l|l}
$\mathrm{n}$ \\
\end{tabular} & GL \\
\hline III & 49 & 218 & 38 & 136 & & & 14 & 161 \\
\hline IV & 45 & 150 & 53 & 167 & 23 & 148 & 22 & 150 \\
\hline $\mathrm{V}$ & 32 & 159 & 35 & 154 & 23 & 147 & 35 & 148 \\
\hline VI & 31 & 145 & 39 & 146 & 50 & 152 & 26 & 149 \\
\hline VII & 13 & 147 & 20 & 151 & 30 & 146 & 27 & 149 \\
\hline VIII & 5 & 132 & 7 & 144 & 35 & 145 & 24 & 144 \\
\hline IX & 4 & 136 & 10 & 145 & 15 & 143 & 13 & 139 \\
\hline $\mathrm{X}$ & 2 & 136 & 8 & 150 & 12 & 141 & 12 & 137 \\
\hline $\mathrm{XI}$ & 8 & 136 & 6 & 139 & 10 & 143 & 10 & 135 \\
\hline XII & 2 & 136 & 3 & 142 & 10 & 140 & 5 & 135 \\
\hline XIII & 4 & 130 & & & 2 & 136 & 2 & 134 \\
\hline XIV & 3 & 141 & & & & & 2 & 137 \\
\hline
\end{tabular}

Parameters of von Bertalanffy equation and power function

\begin{tabular}{|c|c|c|c|c|c|c|c|}
\hline Sex & Year & $\mathrm{L} \infty$ & $\mathrm{K}$ & $\mathrm{t}$ & $\mathrm{W} \infty$ & $\mathrm{k}$ & $\mathrm{n}$ \\
\hline \multirow{3}{*}{$\begin{array}{c}\text { Males and } \\
\text { females }\end{array}$} & 1992 & 36.53 & 0.0988 & -0.365 & $1,006.4$ & 0.01634 & 3.065 \\
\cline { 2 - 9 } & 1974 & 41.14 & 0.0816 & -0.521 & & & \\
\cline { 2 - 9 } & 1975 & 41.82 & 0.0824 & -0.534 & & & \\
\hline & 1976 & 37.68 & 0.0959 & -0.385 & & & \\
\hline \multirow{3}{*}{ Males } & 1992 & 28.82 & 0.1297 & -0.522 & 468.4 & 0.01799 & 3.025 \\
\cline { 2 - 9 } & 1974 & 32.55 & 0.1044 & -0.589 & & & \\
\cline { 2 - 9 } & 1975 & 35.24 & 0.1021 & -0.468 & & & \\
\cline { 2 - 9 } & 1976 & 37.10 & 0.0895 & -0.616 & & & \\
\hline \multirow{3}{*}{ Females } & 1992 & 35.91 & 0.1051 & -0.245 & 966.7 & 0.01619 & 3.071 \\
\cline { 2 - 8 } & 1974 & 48.01 & 0.0632 & -0.854 & & & \\
\cline { 2 - 8 } & 1975 & 39.67 & 0.0945 & -0.315 & & & \\
\cline { 2 - 8 } & 1976 & 37.19 & 0.0993 & -0.356 & & & \\
\hline
\end{tabular}




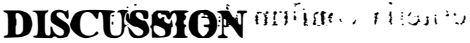

The study shows the Lake Dabie roach to grow' fast 'Folloting the criterion proposed by Wilkonssk [1975] (ie., the length attained in year "6), the population's growth rate is intermediate between "good" and "very good". If orre 'considers the weight attimed in year 6, the growth rate is "very good" and corresponts to sceore' 5 in a 6 -scóte scale. Szczerbowski [1981] suggested a 4-score scale to be used for 'roach. According to that classification, the Lake Dabie roach can be assigned to the highedst-scoring class (the "very fast" growth) until year 8 , following which the growth rate resembles populations of a "fast" growth. The change can be attributed to the decreasing growth rate type, typical of which is a reduction in annual increments with age. Alongside the uniform growth, this is one of the two growth types observed in roach inhabiting Polish lakes. As observed by Wilkonska [1975], the growth type is poorly correlated with growth rate, atthough the decreasing type is more frequent in slower-growing populations. This relationship does not hold for the population studied in this work. The Lake Dabie roach population's fast growth rate can be related - based on the data presented by Wilkońska [1975] - to the geographical location of the lake (the western part of the country) and its being relatively shallow. The two factors enhance the length of the feeding period during the year, provided food resources are adequate.

Growth rate can be changed, however, even given the adequate food resources. The relationship between food and growth is controlled by a very complex set of external and biological factors [Brett 1972]. Different populations of the same species may utilise the energy derived from their food very differently, depending on conditions prevailing in their respective habitats. Some may grow fast, while others may maintain a better condition or store more reserve materials [Sulman 1972]. Variability in roach growth, observed by a numerous authors in different water bodies, can thus result both from differing food resources and from environmental effects on physiological and biochemical processes controlling food utilisation. On the other hand, growth rate of the roach in a water body may stabilise for a long time, provided the habitat does not experience drastic changes [Wilkońska 1975]. This lime of reasoning may lead to the conclusion that Lake Dabie has not experienced drastic changes within the last 20 years or so, because the roach growth indicators obtained in 1992 are almost identical to those of 1974-1976. The growth indicators mentioned include the type and rate of growth, sex-dependent differences in growth; and even the trend towards decreasing growth rates with age. The latter is most probably an artifact related to the selective effects of fisheries. Comparative data on fish condition and chemical composition of tissues would be needed to confirm the conclusion of the relative habitat stability vs. physiological condition of the population. A comparative analysis in the population size during the period in question would be also very helpful

Another problem touched upon in this paper is how representative of the large lake are samples collected, one at a time, from different locations at different times. The samples of 30 50 individuals tumed out to yield data close to mean values calculated from about 200 individuals. However, a risk of an enror does exist at such sample size, as evidence by the presence of significant differences between the mean and the extreme (maximum and minimum) values found here. Inhomogeneity of the samples in terms of sex ratio may be one of the reasons, as sex-dependent differences in growth rate were obvious. One should, however, bear in mind that the differences between the samples of the size dealt with in this work were manifested withm a limited age interval only. No within-age group differences in length were found in the roach aged 1 and older than 7 years. 


\section{CONCLUSIONS}

1. The roach population in Lake Dąbie shows fast length and weight growth rates, the rates being faster than the respective averages in Polish lakes.

2. The length increments were found to decrease with fish age.

3. Having attained sexual maturity, the females grew faster than males, while male grew slightly faster when juvenile.

4. In the seventies (1974 - 1976), the Lake Dąbie roach growth rate was the same as that in 1992.

5. A sample size of 20 - 50 individuals may not be entirely representative in order to characterise the growth rate of roach in a lake as large as the Dąbie, particularly when the samples differ in their sex ratio.

\section{REFERENCES}

Bastidas H.A.P , 1994: Warunki hydrochemiczne jeziora Dąbie i wód przyległych w latach 1963-78 i 1990-91 [Hydrochemical conditions of Dąbie lake and adjacent water bodies in the periods of 1963-78 and 1990-91]. Ph.D. Thesis. Typescript. Agricultural University of Szczecin: 2-8. (In Polish).

Brett J.R. , 1979: Environmental factors and growth. In: Hoar W.S. , D.J. Randall, J.R. Brett: Fish Physiology vol. VIII, Academic Press, London: 599-675.

Filipiak J. , A.Kompowski, I.Krzykawska, S.Krzykawski, J. Szypula, R.Trzebiatowski, W.Zalachowski, 1975 and 1976: Wpływ wód podgrzanych elektrowni Dolna Odra na ichtiofaunę Odry Wschodniej i jeziora Dąbie w latach 1974-1976 [The influence of heated water from Dolna Odra power station on fish fauna of Eastern Oder and Dąbie lake in 1974-76]. Typescripts, Agricultural University of Szczecin: 18-23 and 15-17. (In Polish).

Heese T. , 1992: Optymalizacja metody określania tempa wzrostu ryb za pomocą odczytów wstecznych [Optimalization of the fish growth rate determination method by means of back calculations]. Monograph of Faculty of Overland and Sanitary Engineering Nr 42, Koszalin (In Polish).

Szczerbowski J.A., 1981: Criteria for estimating the rate of growth in fish. Rocz. Nauk Rol. H-99-4: 123-136

Šulmain G.E., 1972: Fiziologo-biochimičeskie osobiennosti godovyh ciklov ryb. [Physiological and biochemical properties of fish seasonal cycles]. Piščevaia promyšlennost, Moskva: 309-313. (In Russian).

Szypula J., 1977: Zastosowanie wielomianów 2-go i 3-go stopnia do charakterystyki wzrostu ryb [Application of second and third order polynomials to fish growth description]. D. Sc. Thesis 52, Agricultural University of Szczecin: 13-25. (In Polish).

Tadajewski A. , D.Rutkowski, 1993: Stan wód jezior Szczecina i okolic oraz kanałów i basenów portu szczecińskiego. [Water quality of lakes in Szczecin with surroundings and of Szczecin port canals and basins]. In: Jasnowska J. (ed.): Stan środowiska miasta i rejonu Szczecina [Status of the environment in the city and district of Szczecin], Szczecin Scientific Society, Chapter 15: 205-218. (In Polish). 
Wilkońska H. , 1975: Zróżnicowanie wzrostu płoci (Rutilus rutilus L.) w jeziorach Polski na tle wanunków środowiska [The differentiation of roach growth in Polish lakes on the background of environmental conditions]. Rocz. Nauk Rol. , H-97-1: 7-28. (In Polish).

Whodzimierz ZALACHOWSKI, Irena KRZYKAWSKA

TEMPO WZROSTU PLOCI-Rutilus rutilus (L.) W JEZIORZE DABIE

STRESZCZENIE

W okresie od lipca do paździemika 1992 roku pobrano 6 prób zawierających łącznie 196 osobników płoci, w tym 58 samców, 134 samice i 4 osobniki o nieoznaczonej płci. Wiek ich określono na podstawie lusek. Tempo wzrostu dhigości zostało wyznaczone za pomoca metody odczytów wstecznych, proy zastosowanin wzoru Rosy Lee $\mathrm{z}$ wartością korekcyją $0.8 \mathrm{~cm}$. Wyliczono parametry równań von Bertalanffy'ego dla werostu długości i ciężaru, a przy analizie wzrostu ryb należących do różnycb grup wieku: astosowany został wielomian drugiego stopnia i współczynnik wzrostu (GL), zaproponowany przez Szypułę (1977). Wykorzystując, pocbodzqce $z$ lat 70 ., nie publikowane dane autorów tej pracy: wskazano zakres zmian wskámików wzrostu w ciqgu prawie 20 lat.

Badania wykazały, że płoć w jeziorze Dąbie należy do najszybciej w kraju rosnących populacji tego gatuoku. Reprezentuje typ wzrostu malejącego, charakteryzujący się spadkiem przyrostów rocznych wraz z wiekiem osobników. Samce $w_{j}$ okresie młodocianym rosną nieco szybciej od samic, jednakże po osiagnięciu dojrzałości płciowej znaczmie szybciej rosną samice. Odnotowano pozomą zmianę tempa wzrostu wraz z wiekiem - młodsze ryby. wykszywały szybszy wzrost niż starsze. Wskazuje to na intensywna eksploatacje zasobów i selektywne działanie rybołówstwa. Materiał porównawczy z lat 7.9 . wykazal, że w ostatnim dwudziestoleciu tempo wzrostu płoci w badanym jeziorze nie uległo zmianie. Świadcza o tym zarówno nakładające się na siebie krzywe wzrostu, jak i analogiczne różnice pomiędzy szybkością wzrostu samic i samców, a ponadto podobne wskaźniki wzrostu ryb z różnych grup wieku

Received: 1995.04.07

Author's address:

Prof. tit. D.Sc. Włodzimierz Załachowski

Department of Fish Biology

Agricultural University of Szczecin

Kazimierza Królewicza 4

71-550 Szczecin

Polska (Poland) 